\title{
Implementasi Crime Prevention Through Environmental Design (CPTED) Pada Fasilitas Parkir Sepeda Motor (Studi Kasus: Kampus Fakultas IImu Budaya USU)
}

\author{
Crime Prevention through Environmental Design (CPTED) \\ Implementation in Motorcycle Parking Facilities (Case Study: Faculty \\ of Cultural Studies USU Campus)
}

\author{
Aulia Malik Affif ${ }^{1}$, Novrial ${ }^{1}$
}

\begin{abstract}
Abstrak: Fenomena tindak kejahatan yang sering terjadi di lingkungan kampus USU adalah pencurian sepeda motor. Bahkan, beberapa kejadian tindak pencurian sepeda motor pada lingkungan USU pun turut diliput media elektronik. Sehingga, diperlukannya sebuah model penataan area parkir yang dapat mengurangi atau menghilangkan resiko terjadinya tindak kriminal. Tujuan penelitian ini adalah untuk membuat model penataan fasilitas parkir sepeda motor Kampus Fakultas Ilmu Budaya USU dengan konsep CPTED. Penelitian ini menggunakan metode kualitatif deskriptif. Penelitian diawali dengan analisa kondisi fisik area parkir kemudian merumuskan model penataan fasilitas parkir sepeda motor Fakultas Ilmu Budaya USU dengan konsep CPTED. Hasil dari penelitian ini adalah, model penataan fasilitas parkir Fakultas Ilmu Budaya USU dengan menerapkan prinsip CPTED menitikberatkan kepada enam cara, yaitu: penambahan pagar tanaman atau hedges; pembangunan portal parkir otomatis dan jalur khusus pedestrian menuju fasilitas parkir; pembangunan atap fasilitas parkir; pembangunan ruang berkumpul mahasiswa; pemasangan speed bump; penggunaan penanda atau signage. Dengan menerapkan enam cara tersebut, diharapkan fasilitas parkir Fakultas Ilmu Budaya USU terbebas dari segala tindak kriminal.
\end{abstract}

Kata kunci: CPTED, crime prevention through environmental design

\begin{abstract}
Most often crime that occurs on the USU campus is motorcycle theft. In fact, several motorcycle theft on the USU campus is covered by electronic media. So there is a need to make a motorcycle parking model to reducing and preventing the opportunity for crime to occur. This research aims to make a model of Faculty of Cultural Studies USU campus motorcycle parking with the CPTED concept. This research using the descriptive qualitative method. This research started with a physical analysis of existing conditions in the motorcycle parking area, then the author developing a motorcycle parking model with the CPTED concept. The result of this research is motorcycle parking model in Faculty of Cultural Studies USU campus is focusing on six ways, i.e: using hedge as fence; using automated system parking portal and pedestrian way from/to parking area; construct parking lot roofing; construct students gathering space; using speed bump; using signage. By applying this six ways, the Faculty of Cultural Studies USU campus motorcycle parking is expected to free from any crime.
\end{abstract}

Keywords: CPTED, crime prevention through environmental design

\footnotetext{
${ }^{1}$ Departemen Arsitektur, Fakultas Teknik, Universitas Sumatera Utara 


\section{PENDAHLUAUN}

Sepeda motor adalah salah satu transportasi yang banyak digunakan oleh masyarakat di Indonesia, terutama bagi masyarakat yang tinggal di kawasan kota. Saat ini, jumlah sepeda motor di Indonesia telah mencapai angka 113 juta unit dan penjualan sepeda motor pada tahun 2019 sebesar 6 juta unit (Detik Oto, 2020). Di Kota Medan sendiri, saat ini jumlah sepeda motor berjumlah 2,7 juta unit (Harian Analisa, 2020).

Namun tingginya jumlah pengguna sepeda motor tersebut, diiringi juga oleh tingginya jumlah tindak pencurian sepeda motor. Menurut data yang dilansir oleh Polda Sumatera Utara, Jumlah Tindak Pidana (JTP) sepanjang tahun 2019 berjumlah 31.388 kasus dan khusus untuk Jumlah Tindak Pidana (JTP) pencurian sepeda motor sebanyak 2.486 kasus (Tribun Medan, 2020).

Universitas Sumatera Utara (USU) adalah salah satu universitas negeri di Kota Medan. Fenomena tindak kejahatan yang sering terjadi di lingkungan kampus USU adalah pencurian sepeda motor. Bahkan, beberapa kejadian tindak pencurian sepeda motor pada lingkungan USU diliput media elektronik, salah satunya berita yang dimuat oleh hetanews.com dengan judul "Curanmor di Kampus FIB USU Terekam CCTV".

Berdasarkan fenomena tersebut, diperlukannya sebuah model penataan area parkir yang dapat mengurangi atau menghilangkan resiko terjadinya tindak kriminal. Tujuan penelitian ini adalah untuk membuat model penataan fasilitas parkir sepeda motor Kampus Fakultas Ilmu Budaya USU dengan konsep Crime Prevention Through Environmental Design (CPTED).

Pencegahan tindak kriminal dapat dilakukan dengan banyak cara, salah satunya adalah melalui Crime Prevention Through Environmental Design (CPTED). Menurut C. Ray Jeffrey, CPTED merupakan sebuah perancangan lingkungan binaan secara efektif dan tepat yang bertujuan untuk mengurangi ketakutan dan insiden tindakan kriminal (Santoso et. al, 2018). Teori CPTED didasari dari argumen yang menyatakan bahwa kebanyakan kejadian kejahatan didukung oleh kesempatan yang tercipta karena desain lingkungannya (Cozens et. al, 2005). CPTED menggunakan pendekatan alamiah dengan cara perubahan fisik lingkungan atau bangunan untuk mengurangi kejahatan terjadi (Tseng et. al, 2004). Menurut Moffat dalam Cozens et. al (2005), terdapat enam prinsip dasar CPTED, yaitu:

1. Penegasan Teritorial (Territoriallity)

Teritorial adalah konsep desain yang mengarah dalam memperkuat gagasan tentang kepemilikan dan "rasa memiliki" pada pengguna ruang yang sah, sehingga mengurangi peluang untuk melakukan pelanggaran dengan mencegah pengguna tidak sah (Cozens et. al, 2005).

2. Pengawasan (Surveillance)

Pengawasan adalah tentang bagaimana desain dapat meningkatkan visibilitas, karena kebanyakan pelanggar tidak ingin diperhatikan. Hal ini dapat dipromosikan atau dihalangi oleh desain lingkungan dan dapat mempengaruhi kejahatan dan persepsi keselamatan dari mereka yang menggunakan ruang tersebut (Cozens \& van der Linde, 2015).

3. Pengendalian Akses (Access Control)

Pengendalian akses berkaitan dengan territoriallity yang membantu pemisahan antara ruang publik dan private dan mengkontrol siapa yang memasuki sebuah lingkungan atau kawasan (Cozens \& van der Linde, 2015).

4. Perlindungan Target (Target Hardening)

Perlindungan target berfokus untuk membuat pelaku kriminal sulit melakukan tindak kriminal dengan mempersempit kemungkinan (Cozens \& van der Linde, 2015).

5. Citra dan Manajemen (Image and Management) 
Memberikan citra positif dan perawatan secara rutin pada sebuah lingkungan binaan menjamin sebuah elemen fisik akan terus berfungsi dengan efektif dan mentransmisikan sinyal positif kepada seluruh pengguna (Cozens, et. al, 2005).

6. $\quad$ Aktifitas Pendukung (Activity Support)

Dukungan aktivitas melibatkan menarik aktivitas yang aman dan sah ke area yang dianggap tidak aman. Ini dicapai melalui desain ruang kota yang cermat dan penggunaan acara lokal, fungsi, dan penggunaan lahan lainnya untuk menarik pengguna yang sah (Cozens \& van der Linde, 2015).

Atlas (2008) menjelaskan bahwa CPTED adalah konsep yang berfokus pada :

1. Lingkungan fisik, keadaan fisik lingkungan dapat dimanipulasi untuk menghasilkan sebuah perilaku yang dapat mengurangi ketakutan dan terjadinya tindak kriminal. Misalnya dengan memberi pagar.

2. Perilaku manusia terkait dengan lingkungan fisiknya, beberapa lokasi seperti menberi celah untuk dilakukannya tindak kriminal, dan yang lainnya tidak.

3. Mendesain ulang atau menggunakan area yang ada lebih efektif lagi untuk mendorong perilaku yang diinginkan dan mencegah perilaku yang tidak diinginkan.

Atlas dalam bukunya $21^{\text {st }}$ Century Security and CPTED menyatakan bahwa tujuan mendesain area parkir yang aman adalah untuk menciptakan atmosphere yang membuat pelaku kriminal merasa di awasi dan meningkatkan kesempatan bahwa mereka akan menemui kesulitan. Area parkir memiliki banyak faktor yang membuat kesempatan sebuah tindak kejahatan terjadi, salah satu penyebabnya adalah rendahnya tingkat aktivitas yang terjadi di dalam area parkir (Atlas, 2008).

\section{METODE}

Penelitian ini menggunakan metode kualitatif deskriptif. Penelitian deskriptif bertujuan untuk membuat deskripsi atas suatu fenomena sosial/alam secara sistematis, faktual dan akurat (Darjosanjoto, 2006). Data primer dikumpulkan melalui observasi lapangan dan wawancara, kemudian data sekunder dikumpulkan melalu studi literatur. Lokasi penelitian berada di area fasilitas parkir sepeda motor Kampus Fakultas Ilmu Budaya Universitas Sumatera Utara, J1. Universitas No. 19, Medan.

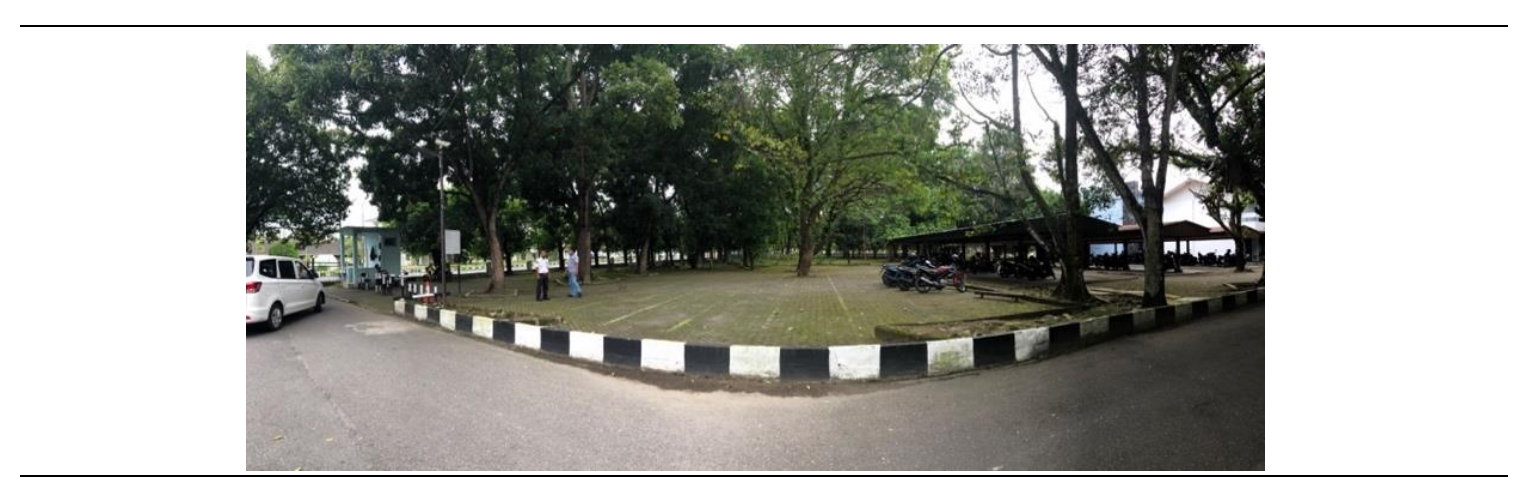

\section{Gambar 1. Lokasi Penelitian}

Tahapan penelitian diawali dengan analisa kondisi fisik area parkir Kampus Fakultas Ilmu Budaya Universitas Sumatera Utara yang ditinjau dengan cara observasi. Analisa kondisi fisik menggunakan 6 prinsip dasar CPTED untuk mengungkap kondisi area parkir. Setelah mengetahui permasalahan-permasalahan yang terjadi, maka penulis merumuskan model penataan fasilitas Kampus Fakultas Ilmu Budaya Universitas Sumatera Utara yang menerapkan prinsip Crime Prevention Through Environmental Design (CPTED). 


\section{HASIL DAN PEMBAHASAN}

\section{Analisa Kondisi Fisik Fasilitas Fisik Parkir Sepeda Motor Kampus Fakultas IImu Budaya USU}

Penegasan Teritorial (Territoriallity)

Area fasilitas parkir Kampus Fakultas Ilmu Budaya USU berada di bagian depan lahan Fakultas Ilmu Budaya USU (Gambar 2a). Berdasarkan hasil analisa penulis, telah terdapat pagar di semua sisi jalan sebagai penegasan teritorial antara jalan dengan Kampus Fakultas Ilmu Budaya USU (Gambar 2b). Kemudian terdapat barrier yang menjadi pembatas area fasilitas parkir dengan area jalan pada Fakultas Ilmu Budaya USU (Gambar 2c).

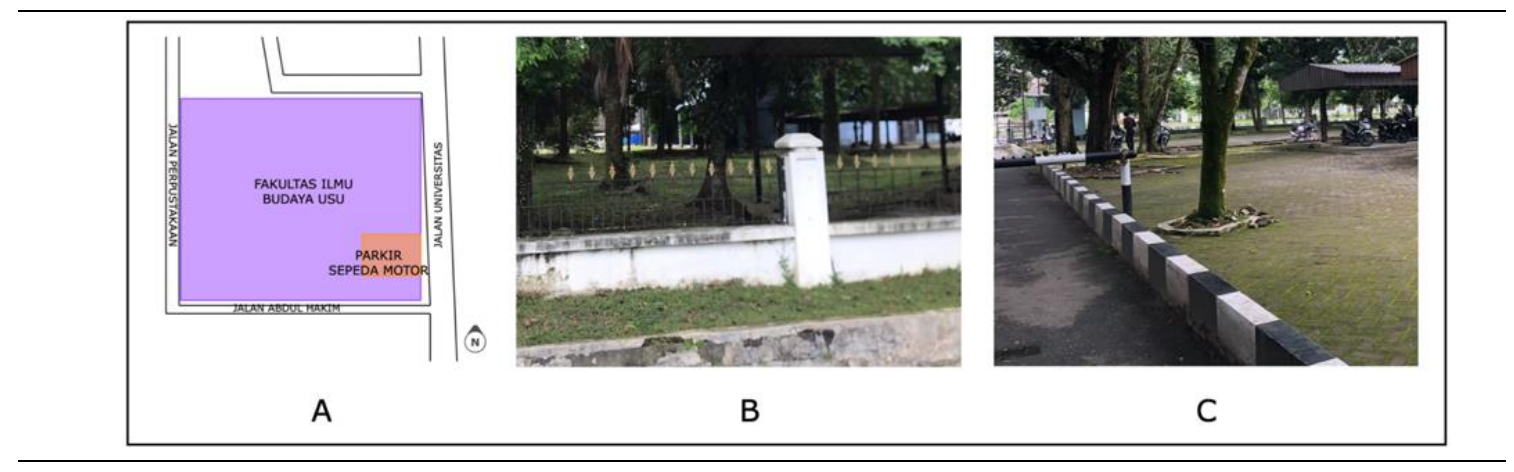

\section{Gambar 2. Analisa Penegasan Teritorial}

\section{Pengawasan (Surveillance)}

Peningkatan pengawasan pada kawasan sangat diperlukan yang dapat berperan dalam keamanan kawasan. Diperlukannya sebuah penataan agar sebuah kawasan yang rawan akan tindak kriminal dapat diawasi dengan mudah dan minim tempat-tempat tersembunyi. Berdasarkan hasil analisa penulis, pengawasan pada fasilitas parkir Kampus Fakultas Ilmu Budaya USU telah cukup baik. Terutama pada bagian area yang berbatasan dengan arus sirkulasi menuju ke dalam Gedung Kampus atau sisi sebelah utara (Gambar $4 a)$.

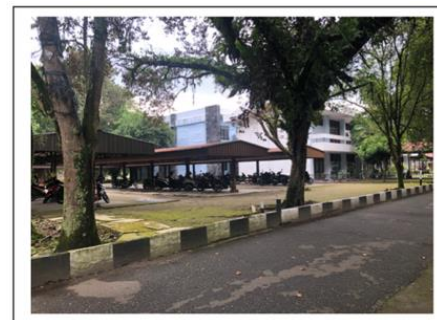

A

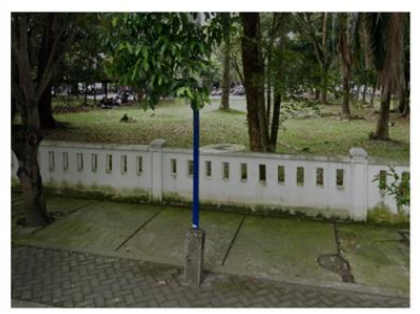

C

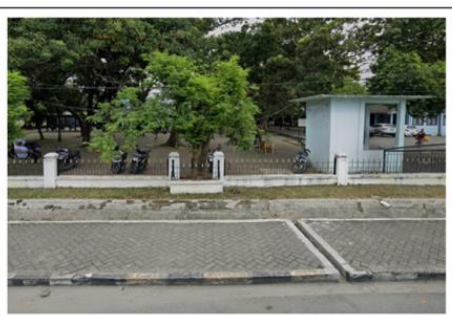

B

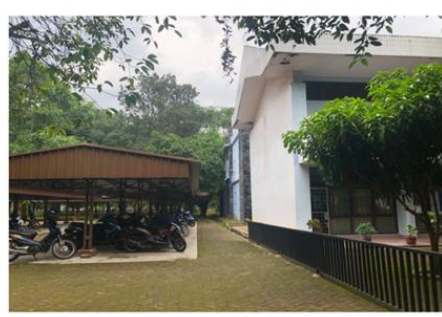

D

Gambar 3. Analisa Pengawasan 
Sisi sebelah timur pun telah dalam kondisi yang cukup baik karena pos petugas keamanan berada di sisi ini, cukup tingginya aktivitas berjalan kaki pada jalue pedestrian di sisi ini dan jaraknya dengan jalur pedestrian hanya dibatasi pagar dan selokan (Gambar 4b). Kemudian, sangat minimnya pengawasan dari bagian selatan bangunan dikarenakan minimnya aktivitas pada sisi ini, dan antara fasilitas parkir dan jalur pedestrian berjarak 25 meter dan ditutupi pepohonan (Gambar 4c). Kemudian pada sisi barat pun pengawasan cukup minim dikarenakan sedikitnya aktivitas pada sisi ini dan ditambah tidak terdapatnya jendela atau bukaan bangunan yang menghadap ke fasilitas parkir (Gambar 4d). Atap area parkir yang terbuat dari material seng memberikan bayangan terhadap objek yang berada di bawahnya sehingga menurunkan pengawasan dan memberi ruang-ruang tersembunyi. Pengendalian Akses (Access Control)

Berdasarkan analisa penulis, akses masuk dan keluar kendaraan pada fasilitas parkir sepeda motor berada di satu titik di dekat gerbang masuk Fakultas Ilmu Budaya USU. Belum terdapat tanda masuk parkir yang sah sehingga pengendara wajib menunjukkan surat kepemilikan kendaraan yang sah seperti STNK atau BPKB sebagai pengendalian akses masuk keluar kendaraan. Sedangkan akses pejalan kaki menuju fasilitas parkir tidak di batasi dan dapat menuju area parkir dari berbagai lokasi Kampus Fakultas Ilmu Budaya USU.

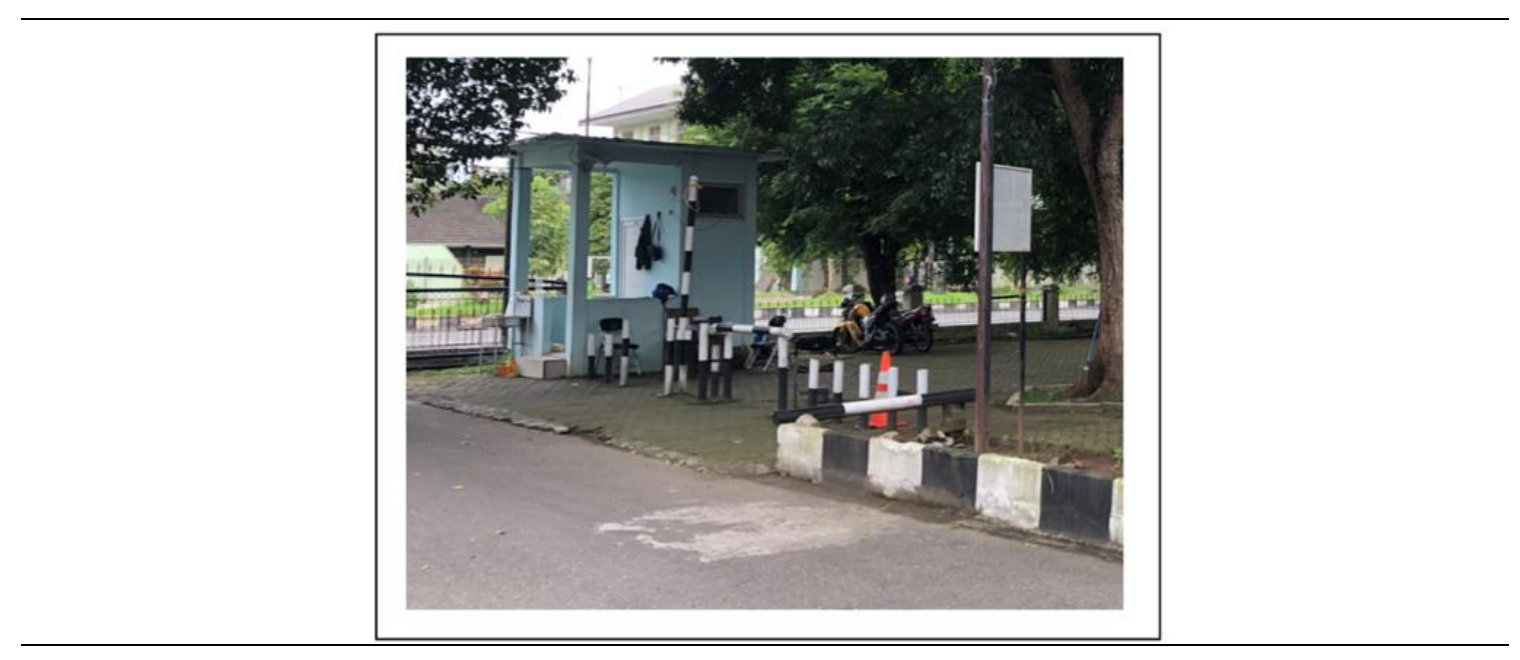

Gambar 4. Analisa Pengendalian Akses

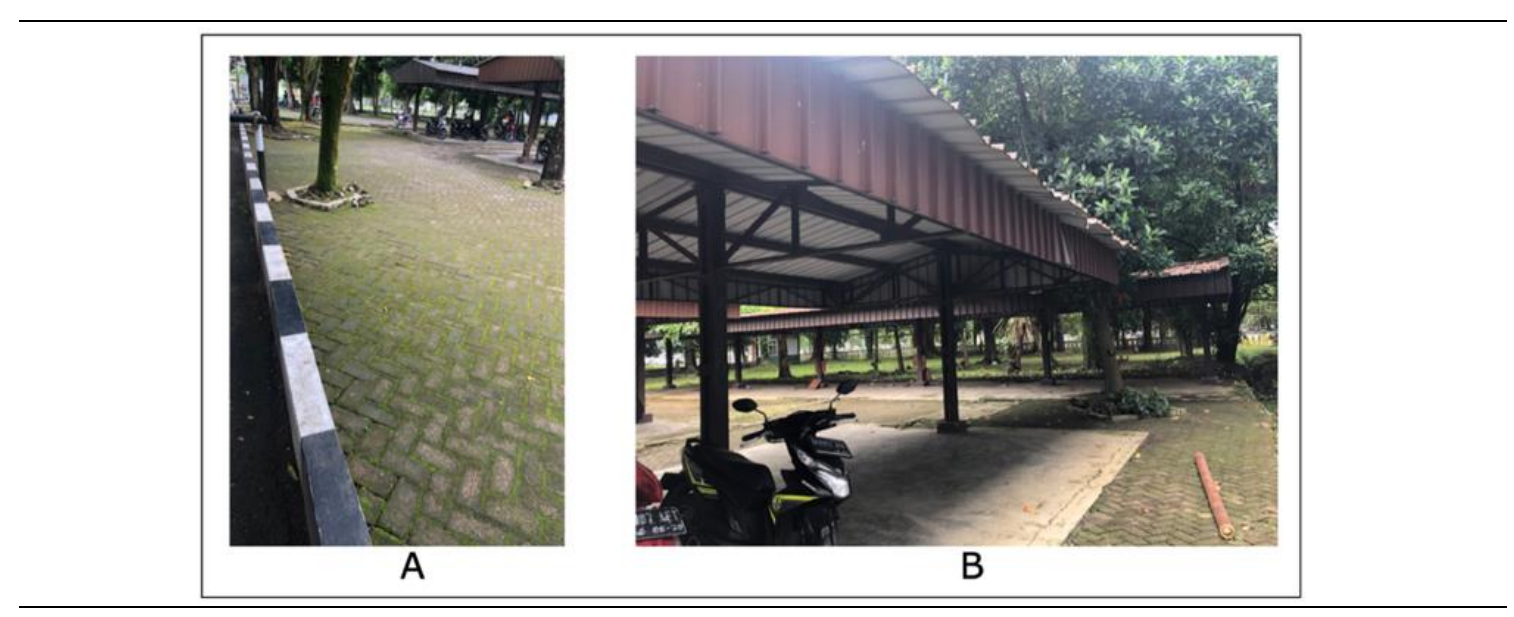

Gambar 5. Analisa Citra dan Manajemen 


\section{Citra dan Manajemen (Image and Management)}

Berdasarkan hasil analisa penulis, pada area parkir belum dilakukannya perawatan atau maintenance yang mumpuni. Hal ini dapat dilihat melalui kondisi fisik material perkerasan lantainya yang sudah berlumut dan masih terdapatnya sampah-sampah yang berserakan di fasilitas parker, Gambar 5.

\section{Aktifitas Pendukung (Activity Support)}

Berdasarkan hasil analisa penulis, aktifitas yang terjadi pada fasilitas parkir hanya aktifitas yang berkaitan dengan parkir seperti memarkirkan kendaraan, mengambil kendaraan. Aktifitas berjalan kaki pun hanya terjadi pada bagian utara fasilitas parkir. Pada fasilitas parkir sepeda motor Fakultas Ilmu Budaya USU, tidak terdapat aktifitas selain aktifitas yang berkaitan dengan parkir dan melintas yang dapat memberikan pengawasan tambahan pada fasilitas parkir.

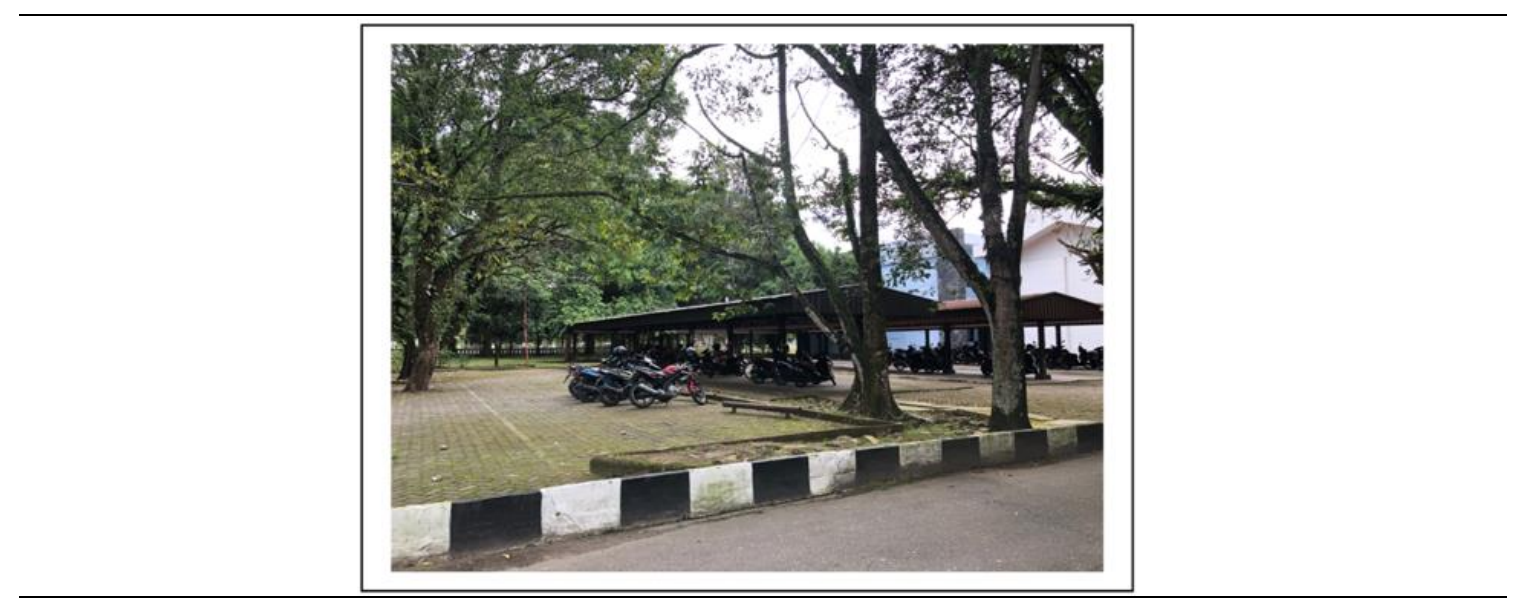

Gambar 6. Analisa Aktifitas Pendukung

Setelah melakukan analisis kondisi fisik fasilitas parkir sepeda motor kampus Kampus Fakultas Ilmu Budaya USU, maka di dapatkan lah temuan-temuan dari setiap variabel dan solusinya (Tabel 1), yang menjadi acuan dalam mengembangkan ide untuk merancang model penataan fasilitas parkir Kampus Fakultas Ilmu Budaya USU dengan konsep CPTED.

\section{Tabel 1. Hasil Analisa Kondisi Fisik}

\begin{tabular}{|c|c|c|}
\hline$a_{r}$ & muan & \\
\hline & $\begin{array}{l}\text { gai batasan antara } \\
\text { s sirkulasi, namun }\end{array}$ & $\begin{array}{l}\text { ng tidak mudah } \\
\text { ki namun tidak }\end{array}$ \\
\hline & & \\
\hline & $\begin{array}{l}\text { Rendahnya pengawasan diakibatkan } \\
\text { rendahnya level aktivitas dan atap } \\
\text { fasilitas parkir mengurangi } \\
\text { pengawasan pada fasilitas parkir }\end{array}$ & $\begin{array}{l}\text { Menghadirkan aktivitas baru pada } \\
\text { fasilitas parkir menciptakan pengawasan } \\
\text { tambahan dan penggunaan material atap } \\
\text { parkir yang tidak mengurangi } \\
\text { pengawasan }\end{array}$ \\
\hline $\begin{array}{l}\text { Penge } \\
\text { Akses }\end{array}$ & $\begin{array}{l}\text { Akses masuk keluar sepeda motor } \\
\text { belum menggunakan tanda masuk } \\
\text { keluar yang sah dan akses pejalan kaki } \\
\text { tidak dibatasi }\end{array}$ & $\begin{array}{l}\text { Perlunya tanda masuk parkir yang sah } \\
\text { dan sistem portal parkir automatis dan } \\
\text { jalur khusus pejalan kaki menuju } \\
\text { fasilitas parkir }\end{array}$ \\
\hline
\end{tabular}




\begin{tabular}{|c|c|c|}
\hline $\begin{array}{l}\text { Perl } \\
\text { Targ }\end{array}$ & $\begin{array}{l}\text { Upaya perlindungan target hanya } \\
\text { dengan kehadiran pos petugas } \\
\text { keamanan dan portal parkir }\end{array}$ & $\begin{array}{l}\text { Perlunya upaya perlindungan target } \\
\text { yang memyebabkan pelaku kriminal } \\
\text { merasa mereka diawasi dan mempersulit } \\
\text { ruang geraknya }\end{array}$ \\
\hline $\begin{array}{l}\text { Citra dan } \\
\text { Manajemen }\end{array}$ & $\begin{array}{l}\text { Fasilitas parkir kurang terawat, } \\
\text { perkerasan lantai berlumut dan banyak } \\
\text { sampah }\end{array}$ & Perawatan berkala fasilitas parkir \\
\hline $\begin{array}{l}\text { Aktivitas } \\
\text { Pendukung }\end{array}$ & $\begin{array}{l}\text { Hanya aktivitas parkir dan melintas } \\
\text { yang terjadi pada fasilitas parkir }\end{array}$ & $\begin{array}{l}\text { Diperlukan penambahan aktivitas pada } \\
\text { fasilitas parkir sehingga pengawasan } \\
\text { pada fasilitas parkir turut serta } \\
\text { meningkat }\end{array}$ \\
\hline
\end{tabular}

\section{Model Penataan Fasilitas Parkir Sepeda Motor Fakultas IImu Budaya USU}

Maka, berdasarkan hasil observasi fisik fasilitas parkir sepeda motor Fakultas Ilmu Budaya USU, berikut ini adalah model penataan fasilitas parkir sepeda motor Kampus Fakultas Ilmu Budaya USU dengan konsep Crime Prevention Through Environmental Design (CPTED).

\section{Penambahan Pagar Tanaman atau Hedges}

Kondisi eksisting pada lokasi penelitian, batasan antara fasilitas parkir dengan area jalan adalah barrier. Diperlukan sebuah pembatas yang lebih baik sehingga dapat memberikan penguatan territorial fasilitas parkir dan memberi pengendalian akses terhadap orang yang akan masuk menuju fasilitas parkir. Sehingga orang yang hendak menuju fasilitas parkir hanya dapat masuk melalui titik akses tertentu dan dapat lebih terkontrol. Gambar 7

\section{Pembangunan Portal Parkir Otomatis dan Jalur Khusus Pedestrian Menuju Fasilitas Parkir}

Portal parkir otomatis dan tiket tanda masuk parkir diberlakukan untuk meningkatkan pengendalian akses terhadap kendaraan bermotor yang masuk dan keluar. Pembangunan Jalur Khusus pedestrian menuju fasilitas parkir pun diberlakukan sehingga petugas keamanan atau orang-orang di sekitar fasilitas parkir dapat dengan mudah melihat siapa yang masuk dan keluar dari fasilitas parkir.

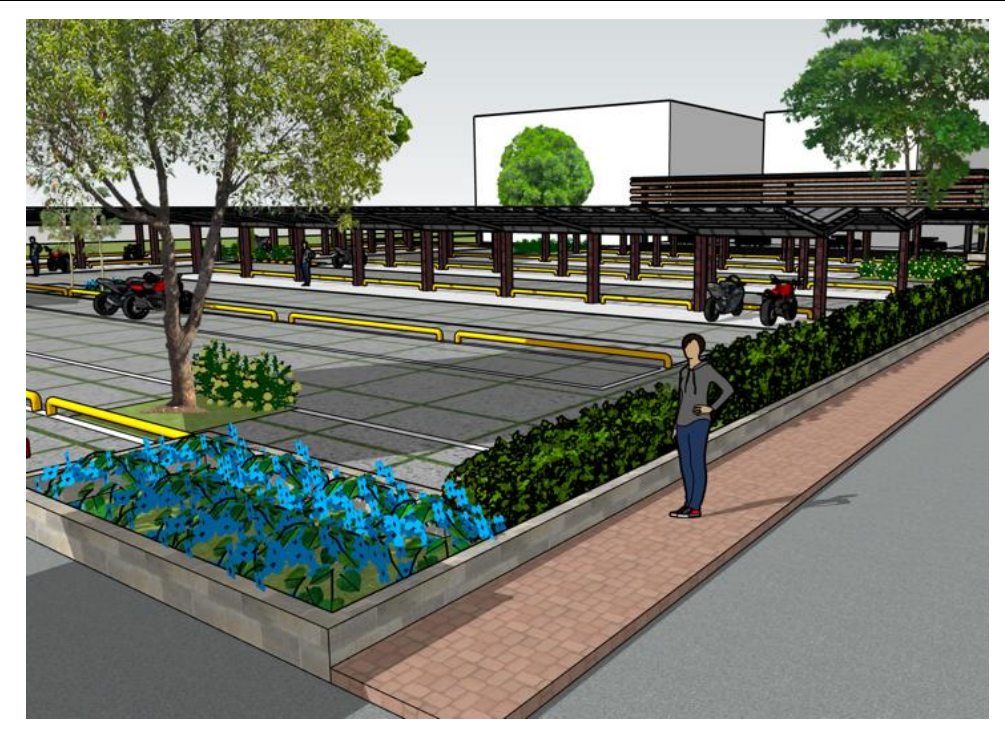

Gambar 7. Penambahan Pagar Tanaman atau Hedges 


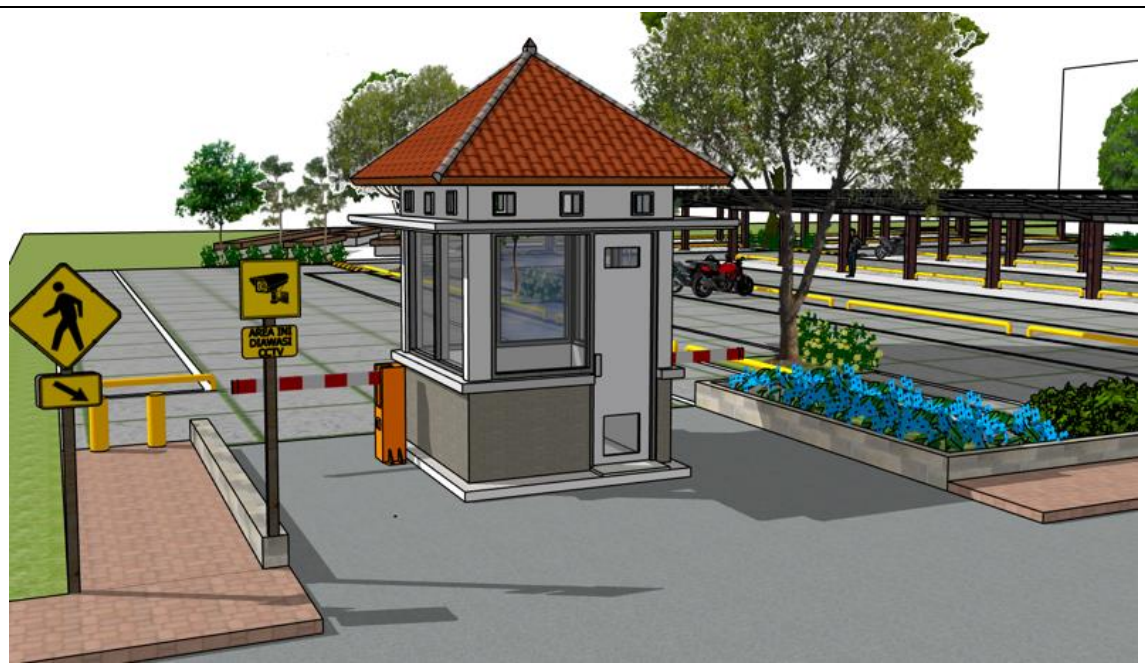

Gambar 8. Pembangunan Portal Parkir Otomatis dan Jalur Khusus Pedestrian Menuju Fasilitas Parkir

\section{Pembangunan Atap Fasilitas Parkir}

Atap fasilitas parkir terbuat dari polycarbonate semi transparan. Dengan penggunaan material ini sebagai penutup atap, tidak terciptanya ruang-ruang tersembunyi sehingga pengawasan pada area parkir dapat meningkat. Gambar 9

\section{Pembangunan Ruang Berkumpul Mahasiswa}

Perlunya menambah fungsi baru sebagai aktivitas pendukung untuk meningkatkan aktivitas pada fasilitas parkir. Penambahan fasilitas baru akan menambah pengawasan sehingga meminimalisir resiko terjadinya tindak kriminal (Atlas, 2008). Dikarenakan mayoritas penggunanya adalah mahasiswa, maka perlunya penambahan ruang-ruang berkumpul mahasiswa untuk bersantai sekaligus untuk belajar. Peletakan ruang berkumpul pada sisi-sisi yang dianggap memiliki pengawasan yang rendah, yaitu pada sisi selatan area parkir dan sisi barat area parkir, Gambar 10, Gambar 11, Gambar 12.

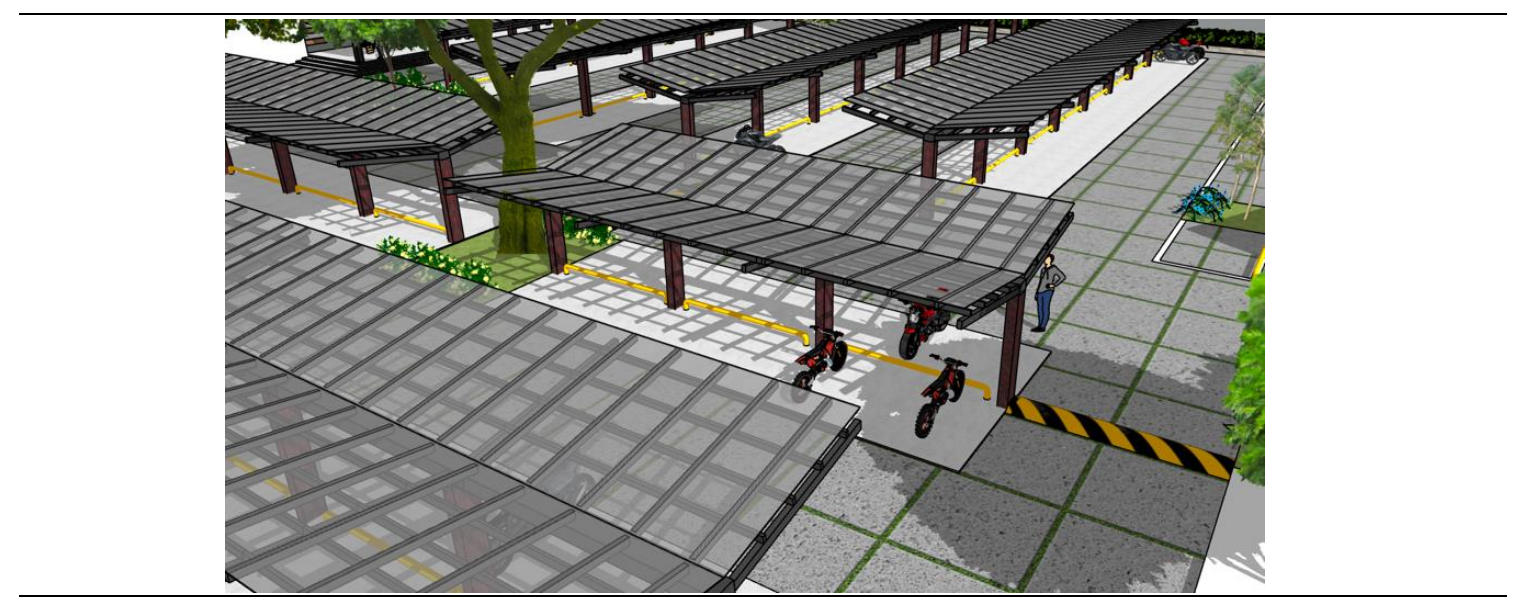

Gambar 9. Pembangunan Atap Fasilitas Parkir 


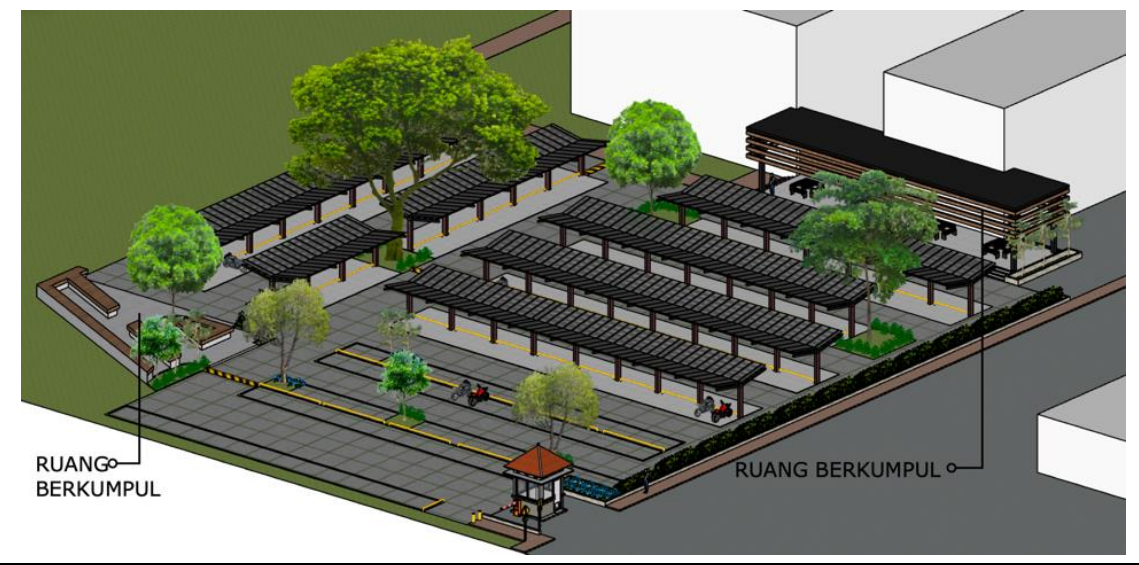

Gambar 10. Pembangunan Ruang Berkumpul Mahasiswa

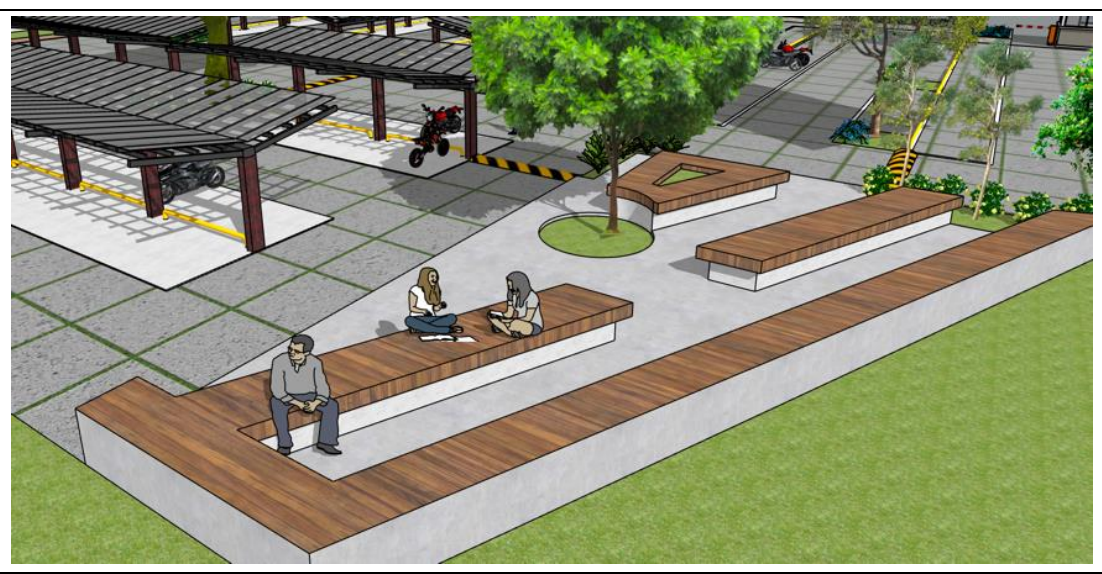

Gambar 11. Pembangunan Ruang Berkumpul Mahasiswa

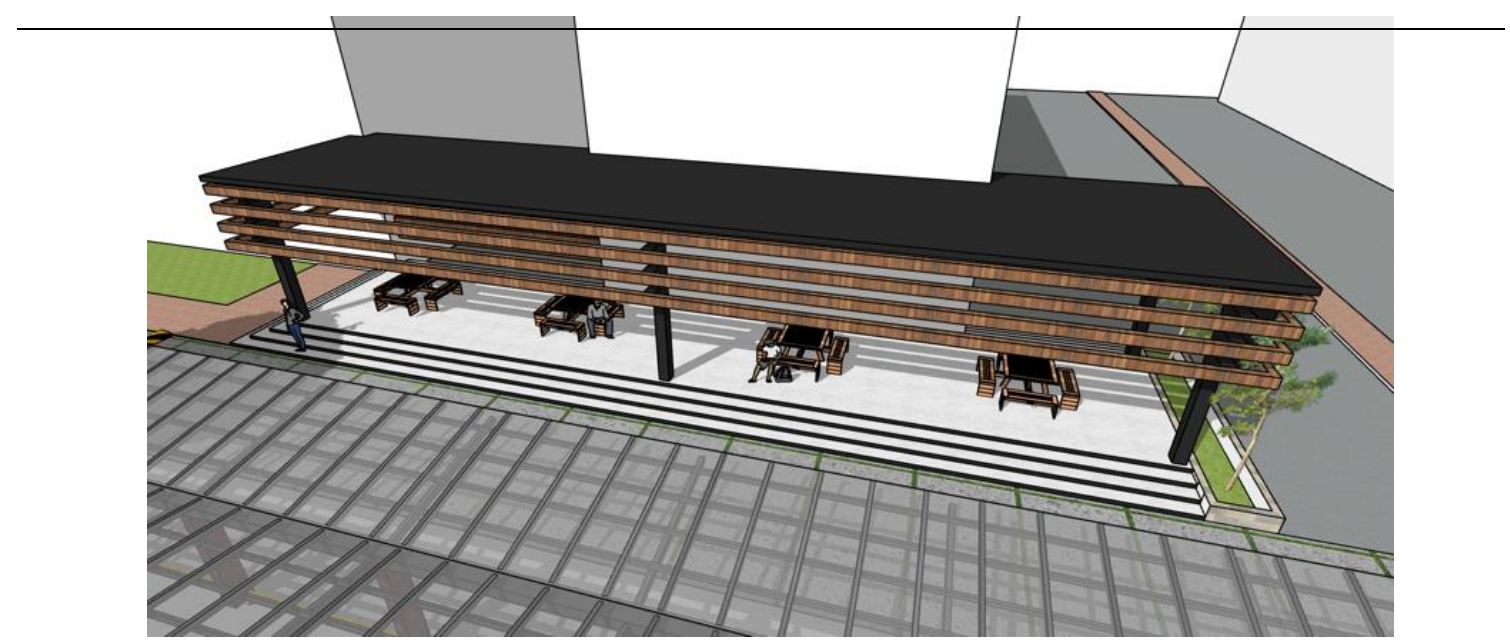

Gambar 12. Pembangunan Ruang Berkumpul Mahasiswa 


\section{Pemasangan Speed Bump}

Katyal (2002) dalam ilustrasinya, menambahkan speed bump sebagai sarana perlindungan target pada area parkir bank. Speed bump berfungsi sebagai penahan laju kendaraan, sehingga kecepatan pada area fasilitas parkir tetap rendah dan sebagai sarana perlindungan target pada fasilitas parkir sepeda motor Fakultas Ilmu Budaya USU, Gambar 13.

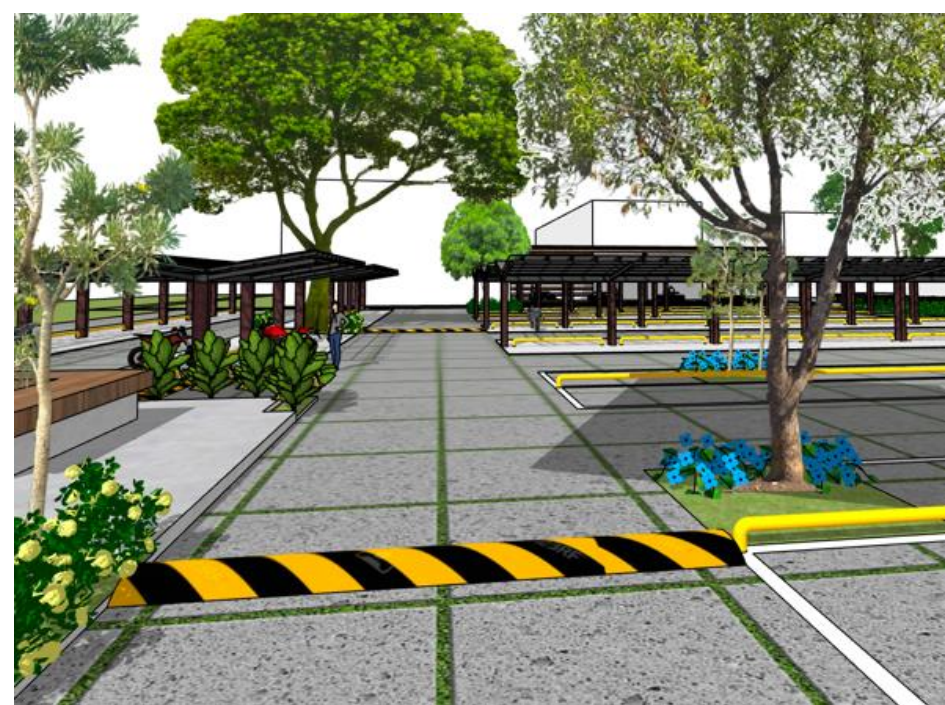

\section{Gambar 13. Pemasangan Speed Bump}

\section{Penggunaan Penanda atau Signage}

Penanda-penanda ini digunakan sebagai sarana komunikasi kawasan terhadap pengguna. Penanda memberikan penguatan territorial terhadap area parkir. Kehadiran penanda dapat memberikan pelaku kejahatan perasaan sedang diawasi (Smith, 1996).

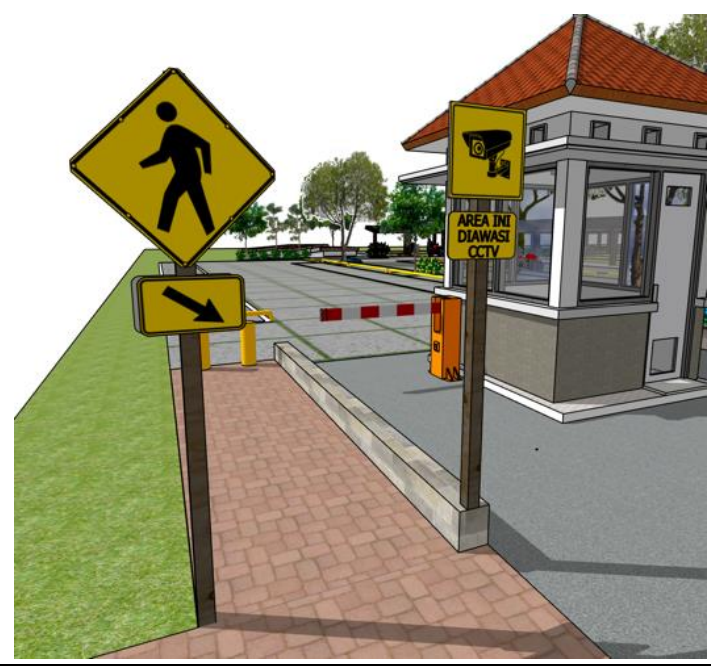

Gambar 14. Penggunaan Penanda atau Signage 


\section{KESIMPULAN}

Model penataan fasilitas parkir Fakultas Ilmu Budaya USU dengan menerapkan prinsip CPTED menitikberatkan kepada enam cara, yaitu: penambahan pagar tanaman atau hedges, pembangunan portal parkir otomatis dan jalur khusus pedestrian menuju fasilitas parkir, pembangunan atap fasilitas parkir, pembangunan ruang berkumpul mahasiswa, pemasangan speed bump, penggunaan penanda atau signage. Dengan menerapkan enam cara tersebut, diharapkan fasilitas parkir Fakultas Ilmu Budaya USU terbebas dari segala tindak kriminal. Model penataan ini membutuhkan dukungan dan partisipasi setiap pihak yang terlibat mulai dari petugas keamanan, mahasiswa, staf pengajar dan para stakeholder.

\section{DAFTAR PUSTAKA}

Analisa Daily. 2019. Menakar Kemacetan Kota Medan di Tahun 2019. Retrieved from: https://analisadaily.com/berita/arsip/2019/4/2/716644/menakar-kemacetan-kota-medan-di-tahun2019/

Atlas RI. 2008. 21st century security and CPTED: Designing for critical infrastructure protection and crime prevention. Boca Raton: CRC Press.

Cozens, P.M., Saville, G., \& Hillier, D. 2005. Crime Prevention Through Environmental Design (CPTED): a review and modern bibliography. Property management.23(5):328-356.

Cozens, P., \& Van der Linde, T. 2015. Perception of crime prevention through environmental design (CPTED) at the Australian train station. Journal of Public Transportation. 18 (4):73-92.

Darjosanjoto, E.T.S. 2006. Penelitian arsitektur di bidang perumahan dan permukiman (1st ed.). ITS Press: Surabaya.

Detik Oto. 2020. Jumlah Sepeda Motor di Indonesia Sudah Lewati 100 Juta Unit!. Retrieved from: https://oto.detik.com/motor/d-4867173/jumlah-sepeda-motor-di-indonesia-sudah-lewati-100-juta-unit

Heta News. 2019. Curanmor di Kampus FIB USU Terekam CCTV. Retrieved from: https://www.hetanews.com/article/149771/curanmor-di-kampus-fib-usu-terekam-cctv

Katyal, N.K. 2002. Architecture as crime control. The Yale Law Journal.111(5):1039-1139.

Santoso, A.K., De Yong, S., \& Tedjokoesomo P.E.D. 2018. Kajian Terapan Konsep Crime Prevention Through Environmental Design (CPTED) pada Interior Rumah Tinggal Tipe Semi-Detached di Sidoarjo. Intra.6(2):797-806.

Smith, M.S. (1996) Crime Prevention Through Environmental Design in Parking Facilities. US Departement of Justice, Office of Justice Programs, National Institute of Justice

Tribun Medan. 2020. Angka Kriminalitas di Sumut 2019 Tergolong Tinggi, Total 31.388 Kasus, Tertinggi Kejahatan Narkoba. Retrieved from: https://medan.tribunnews.com/2020/01/02/angka-kriminalitasdi-sumut-2019-tergolong-tinggi-total-31388-kasus-tertinggi-kejahatan-narkoba

Tseng, C.H., Duane, J., \& Hadipriono, F. 2004. Performance of campus parking garages in preventing crime. Journal of Performance of Constructed Facilities.18(1):21-28. 